\title{
Malformations in embryos of the deposit-feeding amphipod Monoporeia affinis in the Baltic Sea
}

\author{
Brita Sundelin*, Ann-Kristin Eriksson \\ Institute of Applied Environmental Research, Laboratory for Aquatic Ecotoxicology, Stockholm University, \\ S-106 91 Stockholm, Sweden
}

\begin{abstract}
The embryonic development of the deposit-feeding Baltic amphipod Monoporeia affinis (Lindström) was studied from fertilization to hatching. Severe types of aberrant embryonic development are described and the normal variation of the aberrations is estimated. Between 2 and $6 \%$ malformed, 0 and $5 \%$ undifferentiated and 0 and $6 \%$ dead eggs and embryos were observed at different sites in the coastal area of the northern Baltic proper and the Bothnian Sea without local contaminant discharges. The embryonic development of $M$. affinis was described to facilitate the use of the embryo variables in field studies of sediment toxicity. The merits of the different embryo variables as biomarkers in effect monitoring were evaluated. Gravid females were sampled in the receiving waters of 2 different types of pulp mills and an aluminum smeltery. Fecundity (eggs per female) and frequency of malformed, enlarged, undifferentiated and dead embryos per female were determined. Frequency of malformed embryos was higher at industrially affected stations as compared to reference areas ( $p<$ $0.0001, p<0.0001$ and $p=0.003$ respectively). The highest frequencies $(15.3 \%)$ were recorded close to the aluminum smeltery. In reference areas the frequency varied between 1.5 and 4.9 . The number of enlarged embryos with oedema was higher near the pulp mills $(p=0.03, p>0.0001)$, particularly the pulp mill with a bleaching stage, where 25 to $40 \%$ embryos per female were affected. Background frequencies of enlarged embryos $(0.7$ to $3.5 \%)$ were observed outside the aluminum smeltery. Undifferentiated eggs and dead eggs did not correlate to the exposure situation, suggesting these variables are of limited value in effect monitoring of xenobiotics. The frequency of malformed embryos was increased also when fecundity, reproduction success and developmental stage of embryos were unaffected. Thus, the variable is suggested to be particularly toxicant-sensitive and by analysing the number of malformed embryos of $M$. affinis an early warning of affected populations could be provided.
\end{abstract}

KEY WORDS: Monoporeia affinis - Reproduction - Embryonic development - Malformed embryos · Biomarker - Effect monitoring · Contaminated sediment - Baltic Sea

\section{INTRODUCTION}

Soft sediments dominate and represent an important component of the Baltic ecosystem in the recycling of nutrients and toxic substances. Due to physical adsorption and chemical bonds a high proportion of pollutants become highly enriched in sediments compared to the overlying water (Förstner 1987). Once impacted, sediments may remain contaminated for years, with long-lasting or chronic contamination of the benthos (Giere 1993).

\footnotetext{
•E-mail: brita.sundelin@itm.su.se
}

Deposit-feeding invertebrates are often exposed to 2 sources of contamination: ingestion of contaminated particles and accumulation from the interstitial water (Moore et al. 1979, Landrum \& Robbins 1990). Sediment-living benthos are thus included in the monitoring programmes of industries bordering the Baltic, and during the 1970s and 1980s a reduction in abundance and biomass was generally considered to be caused by toxic pollutants. These variables are sensitive to a wide variety of environmental conditions because organisms integrate the effects of summed influences, like predation, competition and pollution. However, the community variables often fail to distinguish between the different influences. The value of using them to assess 
pollutant damage depends on the ability to distinguish natural changes from those induced by the pollutant. In the receiving waters of many pulp mills, where organic enrichment accompanies toxic substances, both abundance and biomass were shown to increase (Pearson 1975, Sundelin 1989, Holton et al. 1993), partly depending on growth-stimulating properties of the bleached kraft mill effluents (BKME), which means that stimulatory effects might confound inhibitory effects, such as effects on reproduction (Sundelin 1988, 1989).

Due to the low sensitivity of community variables when monitoring the effect of pollutants, ecosystem effects could arise before we have identified the damage. Thus, there is an urgent need for sensitive early warning biomarkers with a low response to natural climate variables in effect monitoring of the benthic ecosystem (Davis 1993). In the northern Baltic proper and the Gulf of Bothnia with 3 dominating macrofauna species the need is even more obvious, since the low diversity of macrofauna implies difficulties in interpretation of diversity measurements.

The general susceptibility of sediment-living amphipods to pollutants (Conlan 1994, Coyle \& Highsmith 1994) has contributed to our special interest in the Baltic deposit-feeding amphipod Monoporeia affinis (Lindström) for ecotoxicological studies. $M$. affinis is by far the most productive and abundant macrofauna species of the Baltic soft bottoms. Great efforts have been made to improve the comprehension of biology and ecology of the amphipod $M$. affinis (Segerstrale 1937, Cederwall 1977, Andersin et al. 1984, Elmgren et al. 1986, Leonardsson et al. 1988, Lopez \& Elmgren 1989, Hill 1991, Olafsson \& Elmgren 1991, Sarvala \& Uitto 1991, Lindström 1992, Leonardsson 1994) but despite good knowledge of the reproduction cycle (Segerstråle 1967, 1970, 1971, Steele \& Steele 1986) there are no investigations reported of the mating and embryonic development.

Fifteen years of ecotoxicological studies in soft-bottom microcosms have demonstrated toxicant-sensitive variables in the embryonic development of Monoporeia affinis. When exposed to heavy metals, chlorinated organic compounds, pulp mill effluents or contaminated sediments, the frequency of malformed embryos increased significantly as compared to control microcosms (Sundelin 1983, 1984, 1988, 1989, Eriksson et al. 1996). The effect also arose in low concentrations that did not demonstrably affect the reproduction success, fecundity and rate of embryo development, indicating that embryogenesis is even more sensitive than other variables of the reproduction cycle. The microcosm develops in good accordance with the parent system in situ, suggesting the results are relevant to natural conditions (Sundelin 1989, Sundelin \& Elmgren 1991). However, before the embryo variables can be used for monitoring effects of contaminated sediments, the laboratory results must be validated in situ. Further, to distinguish the effects caused by pollutants, the normal variation for the aberrations should be estimated.

\section{MATERIAL AND METHODS}

Embryonic development of Monoporeia affinis. To describe the mating and embryonic development of $M$. affinis, data from laboratory experiments and surveys in contaminated recipients were used (for detailed information, see Elmgren et al. 1983, Sundelin 1983, 1989, 1992, Eriksson et al, 1996). To follow the embryonic development in detail, live $M$. affinis were collected with a benthic sled in October from 30 to $40 \mathrm{~m}$ depth near the Askö Laboratory, a field station of Stockholm University in the Baltic proper (Blomqvist \& Lundgren 1996). Fifty amphipods (25 males +25 females) were added to 10 replicates of soft bottom microcosms according to Sundelin (1983), about 1 mo before mating in November and the embryogenesis was followed until hatching in February.

To estimate the normal variation of the different embryonic aberrations we examined gravid females of Monoporeia affinis for 4 yr (1994 to 1997) at reference sites in the Baltic proper and the Bothnian Sea. Five sediment samples at each of 7 sites in the Baltic proper and 5 sites in the Bothnian Sea were taken with a van Veen grab during the first week in February. Sediment was sieved through a $1 \mathrm{~mm}$ net and gravid females of $M$. affinis extracted from sediments were analysed in terms of different embryo variables. During the embryo analysis the living females were examined for fertilization success and fecundity (eggs female ${ }^{-1}$ ). Eggs and embryos were analysed using a stereomicroscope for stage of embryo development, different types of malformed embryos, which have been proved not to survive hatching, enlarged embryos with no other visible damage, undeveloped/unfertilized (henceforth called undifferentiated) and dead eggs. To minimize the risk of a subjective assessment 50 broods were independently analysed by 2 persons to check the agreement of the estimation.

Embryo variables in pollution monitoring. Investigation areas: To test the sensitivity of the different embryo variables in pollution monitoring, gravid females of Monoporeia affinis were sampled in the vicinity of different types of industries. Two recipient areas outside pulp mills on the Swedish coast of the Bothnian Sea (industry A) and the Bothnian Bay (industry B) were surveyed in 1991 and 1996 respectively and a recipient area outside an aluminum smeltery (industry C) on the coast of the Bothnian Sea was investigated in 1994 . 
Industry $\mathrm{A}$ : a kraft pulp mill, producing ECF (elemental chlorine free)-bleached sulphate pulp, is situated south of Hudiksvall. Six stations in a pollution gradient and 2 reference stations $40 \mathrm{~km}$ north of the recipient were included (Fig, 1A, Table 1). There are no other known local discharges of pollutants. The reference stations were located within the single uncontaminated area within a distance of $100 \mathrm{~km}$ north and south of the mill, with sediment characteristics matching those of stations in the recipient area. Presence of specific markers of bleaching effluents, e.g. chlorinated guaiacols, was negatively correlated to the distance from the pulp mill and is further described by Sundelin \& Eriksson (1996). Depth varied between 25 and $60 \mathrm{~m}$ (Table 1).

Industry B: 2 kraft pulp mills, BI and BII, are located near Piteå. Both mills produce kraft liner, consisting of unbleached sulphate pulp, unbleached recycled fiber pulp and to a minor extent TCF (total chlorine free)bleached sulphate pulp. In the recipient of mill BI, there are no other known discharges, while the receiving waters of mill BII are possibly influenced by municipal waste waters from Piteå and an oil port, suggesting a more complex pollutant situation. Therefore, station locations were mainly selected relative to pulp mill BI. Three stations within the recipient area of mill BI (a fourth recipient station B7 was selected because of its location relative to pulp mill BII) and 3 stations north and 3 stations south of the recipient area were included (Fig. 1B). All stations in the study are shallow and depth varies between 5 and $12 \mathrm{~m}$ with the exception of Stn B9, with a depth of $60 \mathrm{~m}$ (Table 1).

Industry $\mathrm{C}$ : the third investigation was performed in the bay of Sundsvall outside an aluminum smeltery. High emissions of polycyclic aromatic hydrocarbons (PAHs) (Näf et al. 1992) resulted in very high concentrations of PAHs in settling particulate matter, bottom sediments and the bivalve Macoma balthica (L.) near the smeltery (Näf et al. 1994). In addition to the PAH discharges, the area is possibly influenced by pulp and paper mills north and a chemical industry south of the smeltery. Three stations in an expected southward pollution gradient of the aluminum smeltery, 1 station
A

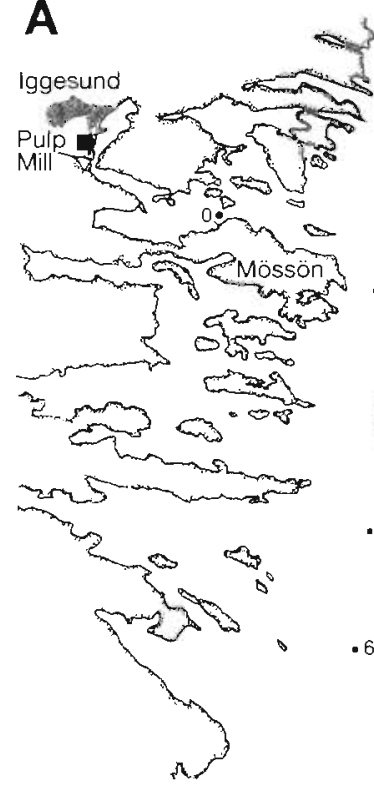

Fig. 1. Investigation areas of (A) survey $A,(B)$ survey $B$ and $(C)$ survey $C$ (A) The reference Stns 1 and 2 on the inserted map are situated $40 \mathrm{~km}$ north of the pulp mill. (B) The recipient areas of the 2 pulp mills are marked with arrows. (C) The reference Stns 1 to 4 on the inserted map are situated about $85 \mathrm{~km}$ north of smeltery (marked with an arrow)

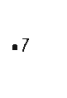

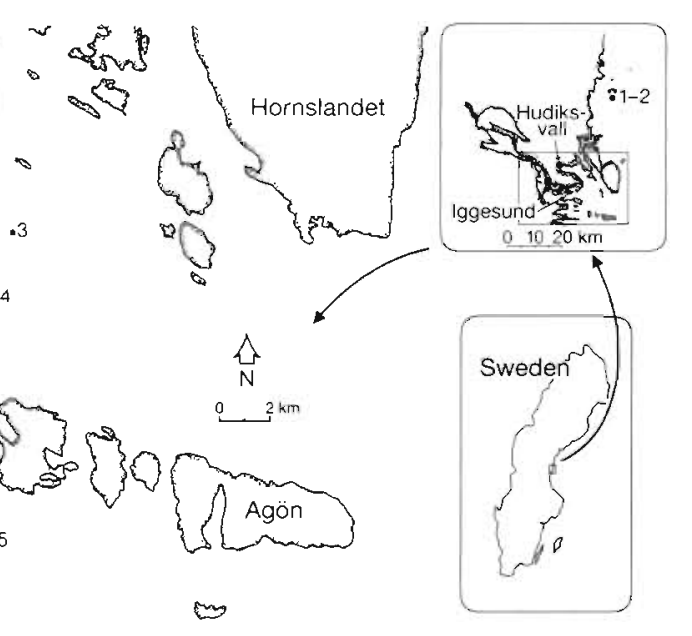

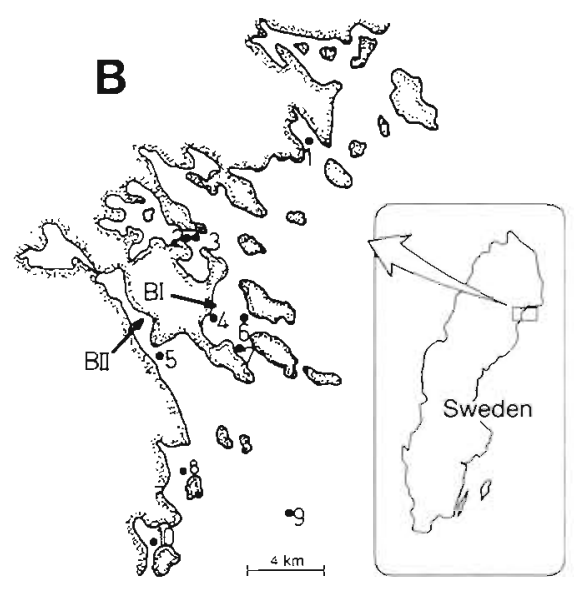

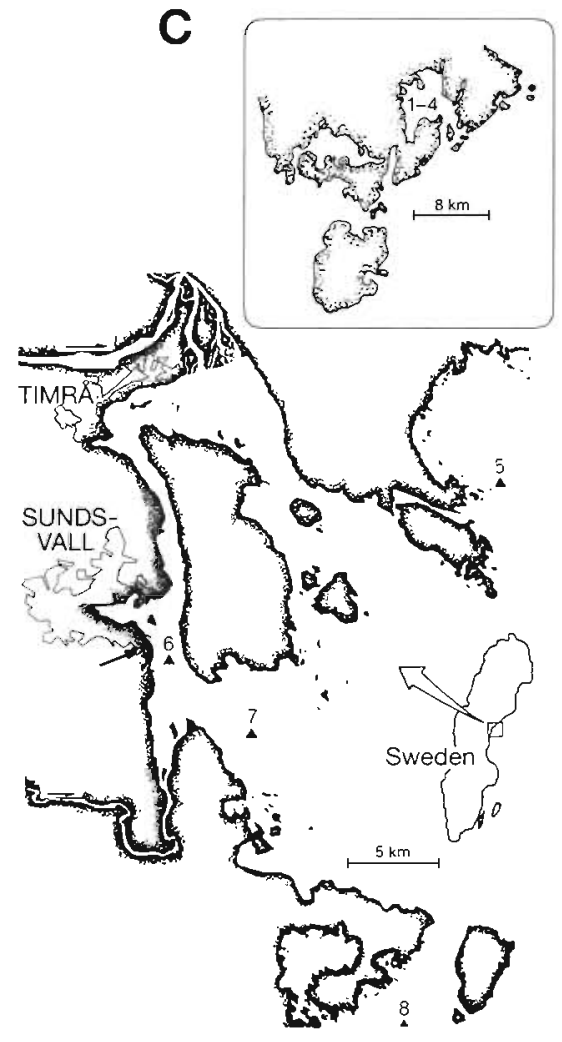


Table 1. Distance of sampling stations from industries, organic content measured as loss of ignition, depth and numbers of females analysed at stations included in the recipient surveys. No amphipods were found at the near-mill Stn AO. Stations marked with - distance are located north of the industries

\begin{tabular}{|c|c|c|c|c|}
\hline Stn & $\begin{array}{l}\text { Distance } \\
(\mathrm{km})\end{array}$ & $\begin{array}{c}\text { Organic } \\
\text { content }(\%)\end{array}$ & $\begin{array}{l}\text { Depth } \\
(\mathrm{m})\end{array}$ & $\begin{array}{l}\text { No. of } \\
\text { females }\end{array}$ \\
\hline \multicolumn{5}{|c|}{ Industry $\mathrm{A}$, a pulp mill in the Bothnian Bay } \\
\hline A1 & -40 & 8 & 60 & 12 \\
\hline A2 & -40 & 4 & 59 & $4 \overline{7}$ \\
\hline AO & 3 & 12 & 18 & - \\
\hline A3 & 9 & 7 & 25 & 8 \\
\hline A4 & 9 & 4 & 30 & 27 \\
\hline A5 & 17 & 10 & 47 & 24 \\
\hline A6 & 21 & 10 & 56 & 16 \\
\hline A7 & 24 & 9 & 57 & 14 \\
\hline \multicolumn{5}{|c|}{ Industry BI and BII, pulp mills in the Bothnian Bay } \\
\hline B1 & -22 & 2 & 10 & 104 \\
\hline B2 & -10.5 & 4 & 5 & 65 \\
\hline B3 & -10.5 & 6 & 8.5 & 81 \\
\hline B4 & 1 & 2 & 7.5 & 111 \\
\hline B5 & 2.5 & 2 & 5 & 39 \\
\hline B6 & 3 & 4 & 7.5 & 79 \\
\hline B7 & 4 & 3 & 8.5 & 63 \\
\hline B8 & 20 & 14 & 9.5 & 123 \\
\hline B9 & 22 & 3 & 64 & 21 \\
\hline B10 & 29 & 7 & 12 & 79 \\
\hline \multicolumn{5}{|c|}{ Industry $C_{\text {, }}$ an aluminum smeltery in the Bothnian Sea } \\
\hline C1 & -85 & 5 & 49 & 174 \\
\hline $\mathrm{C} 2$ & -85 & 7 & 69 & 166 \\
\hline $\mathrm{C} 3$ & -85 & 6 & 69 & 139 \\
\hline $\mathrm{C} 4$ & -85 & 7 & 59 & 335 \\
\hline C5 & -22 & - & 69 & 47 \\
\hline C6 & 0.7 & 10 & 30 & 88 \\
\hline C7 & 5.5 & 9 & 60 & 50 \\
\hline $\mathrm{C} 8$ & 23 & 8 & 65 & 50 \\
\hline
\end{tabular}

$22 \mathrm{~km}$ north and 4 more distant reference stations about $85 \mathrm{~km}$ north of the smeltery were included (Fig. 1C). Depth at different stations varies between 30 and $50 \mathrm{~m}$ (Table 1).

Sampling: Samples from the Bothnian Sea (survey A and C) were collected at the end of January from an icebreaker. Due to severe ice conditions in shallow areas as from December, samples from the Bothnian Bay (survey B) were collected in November. The sediment samples for organic content were collected with a modified Kajak corer (Blomqvist \& Abrahamsson 1985), while amphipods were collected with a sediment sled (surveys A and B) or a ponar grab sampler (Powers \& Robertson 1967) (survey C). Depending on abundances, 8 to 360 gravid females were collected at each station (Table 1). The stenotherm coldwater amphipods were transported alive at $4{ }^{\circ} \mathrm{C}$ to the laboratory, and sediment and 150 gravid females from each sampling station in survey B were transferred to flowthrough microcosms (Sundelin 1983) until the embryo analysis at the end of January.
Statistical evaluation: Data were analysed with the Kruskal-Wallis test and main effects were further examined by the Mann-Whitney $U$-test followed by Holm's procedure, a simple sequentially rejective multiple test procedure (Holm 1979). Pearson's correlation test was used for the relationship between fecundity and organic content of the sediments, while linear regression was used to test the relationship between fecundity, malformation and distance. The conventional significance level of $\alpha<0.05$ was applied.

\section{RESULTS}

\section{Mating and embryonic development}

\section{Normal development}

Before mating, the female oocytes are separated into easily distinguished eggs (Fig. 2A, B). A pair of spermatophores are visible in the anterior part of the male body (Fig. 2E, F). No precopulatory stage was observed. Empty sperm sacs were found in brood pouches containing recently fertilized eggs, suggesting males deposit sperm in the marsupium of recently moulted females, whereupon ova are liberated and extruded into the brood pouch where fertilization takes place.

The unfertilized eggs are full of oil droplets and vary in colour from bright yellow to orange or brown-red. In the several thousand examined females, the eggs of each brood were almost without exception of the same colour and at the same stage of development. Nine developmental stages were distinguished (Table 2). The first 2 cleavage divisions are total (Fig. 3A), resulting in 4 cells, 2 smaller than the others. The next division results in 4 small micromeres lying upon 4 larger macromeres (Fig. 3B). The unpigmented and yolkfree micromeres give rise to a ventral germinal disc. The micromeres extend over the egg surface and surround the lipid-rich yolk cells, derived from the macromeres (Fig. 3D). Egg size is unchanged until the blastula stage (Fig. 3D, E) after which gastrulation occurs, the outer egg membrane bursts and the embryo is allowed to increase in size. Somites of the antennulary, mandibulary and maxillary segments appear and a ventral groove, the caudal furrow, which separates the developing cephalothorax and abdomen, becomes apparent (Fig. 3F) and the characteristic comma-like shape of the embryo develops (Fig. 3G-I). The mid-gut extends backwards, containing large multinucleate pigmented yolk cells (Fig. 3I, J). Paired budlike appendages develop (Fig. 3J, K) and the head region with the clublike antenna can be recognized (Fig. 3J-L). The head region appears distinctly, the first and second antenna 
Table 2. Monoporeia affinis. Description of eggs in each stage of embryonic development. Nine developmental stages were adopted for embryos. Some of these coincide with those of McCahon \& Pascoe (1988a)

\begin{tabular}{|c|c|c|}
\hline $\begin{array}{l}\text { Stage of } \\
\text { development }\end{array}$ & Length (mm) & Embryo description \\
\hline 1 & $0.47-0.50$ & $\begin{array}{l}\text { The newly fertilized egg during the first } 3 \text { cleavages; the egg membrane and the vitelline } \\
\text { membrane tightly bound to the yolk cells are visible. Cleavages are initially total but later } \\
\text { become superficial, see Fig. } 3 \mathrm{~A}-\mathrm{B}\end{array}$ \\
\hline 2 & $0.47-0.50$ & $\begin{array}{l}>8 \text { cells. There is a synchrony of divisions of the larger macromeres and the smaller } \\
\text { micromeres until } 64 \text { cells. Fig. } 3 \mathrm{C}\end{array}$ \\
\hline 3 & $0.47-0.50$ & $\begin{array}{l}\text { The blastula stage. The small micromeres divide more rapidly than the macromeres, } \\
\text { resulting in a ventral non-pigmented germinal disc, which extends over the surface of the } \\
\text { egg, enclosing the yolk cells, constituting the blastoderm. See Fig. 3D. Embryonic devel- } \\
\text { opment until gastrulation takes about } 1 \text { mo }\end{array}$ \\
\hline 4 & $0.53-0.58$ & $\begin{array}{l}\text { Gastrulation starts from the posterior region of the germinal disc. Ventrally gastrulation } \\
\text { proceeds by the proliferation of cells inwardly to form the embryonic mesoderm and } \\
\text { endoderm. At this stage the outer egg membrane bursts and the developing embryo is } \\
\text { allowed to increase in size. Later a narrow groove is formed which develops into the } \\
\text { caudal furrow; see Fig. 3E, F }\end{array}$ \\
\hline 5 & $0.59-0.63$ & $\begin{array}{l}\text { The differentiation of appendages and embryo organs. After gastrulation the embryo is } \\
\text { characterised by its comma-like shape and the dorsal organ is formed. Fig. } 3 \mathrm{G}, \mathrm{H}\end{array}$ \\
\hline 6 & $0.66-0.69$ & $\begin{array}{l}\text { The midgut extends backwards, cephalothorax is visible and the budlike limbs begin to } \\
\text { develop. The dorsal organ is at maximum size. Fig. } 3 \mathrm{I}-\mathrm{K}\end{array}$ \\
\hline 7 & $0.70-0.73$ & $\begin{array}{l}\text { Clublike antennae of the cephalothorax develop and appendages are segmented and the } \\
\text { first pigments of the eyespot appear. Fig. } 3 \mathrm{~L}, \mathrm{M}\end{array}$ \\
\hline 8 & $0.77-0.81$ & $\begin{array}{l}\text { The dorsal organ has regressed and the compound eye is fully developed and clearly } \\
\text { visible. Peristalsis begins in the midgut and the limbs and body move. Fig. 3N }\end{array}$ \\
\hline 9 & $1.45-1.55$ & The newly hatched juvenile. Fig. 30 \\
\hline
\end{tabular}

have grown considerably and the pigment of the eyespot is discernable (Fig. 3M). Later, the compound eye is clearly visible and the amphipod is fully formed before hatching (Fig. 3N). Peristalsis begins in the midgut and the limbs and body move. Spasmodic contractions of the body cuticle and movement of the limbs cause rupture of the embryo membrane and the juvenile (Fig. 3O) is liberated. The yolk remains for about
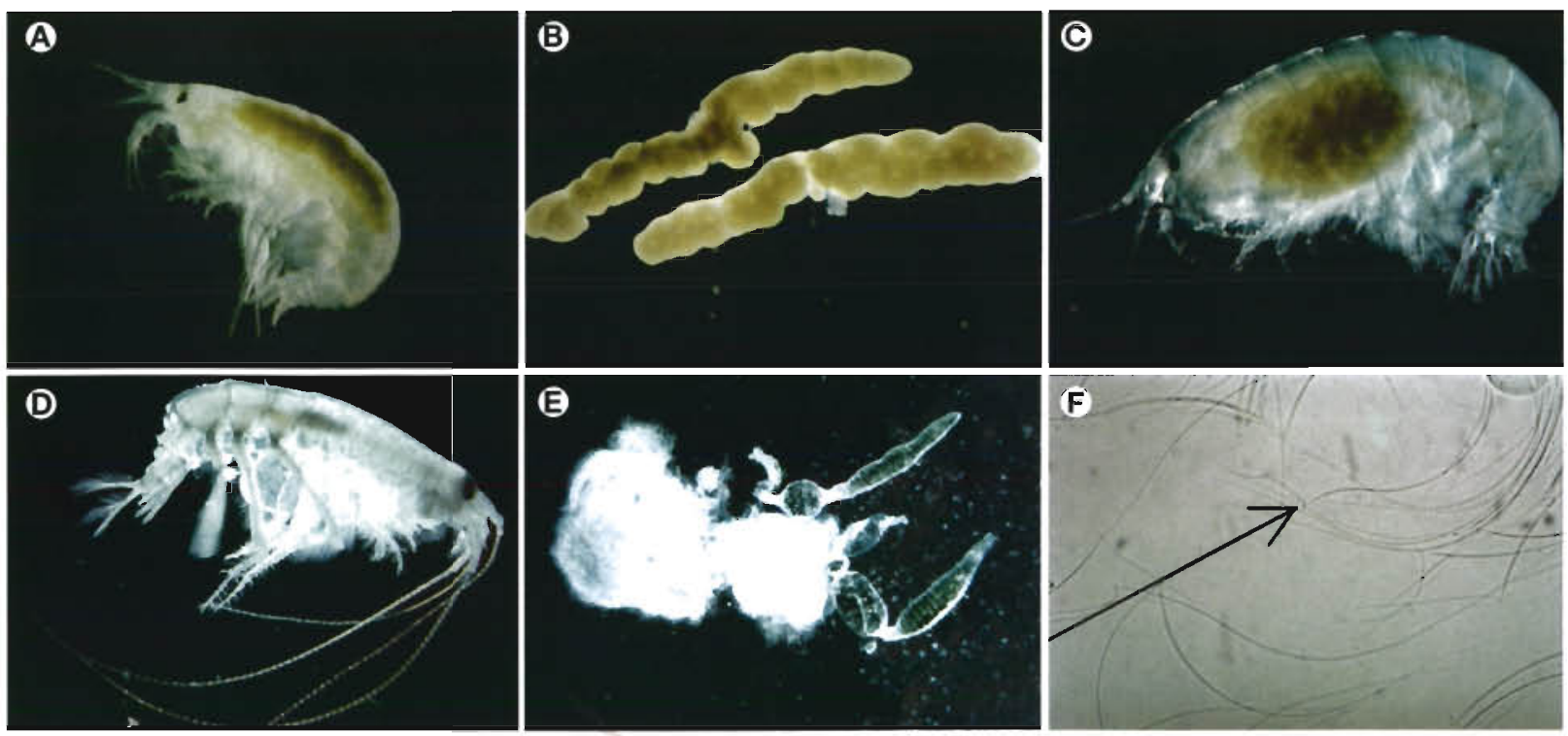

Fig. 2. Reproduction cycle of Monoporeia affinis. (A) Unfertilized female with oocytes; (B) mature female oocytes with unfertilized eggs, (C) fertilized female with eggs in the marsupium; (D) mature male with elongated antennae and enlarged complex eyes; (E) pair of spermatophores with sperms $(F)$ sperms, the sperm head and the mobile tail is illustrated with an arrow 

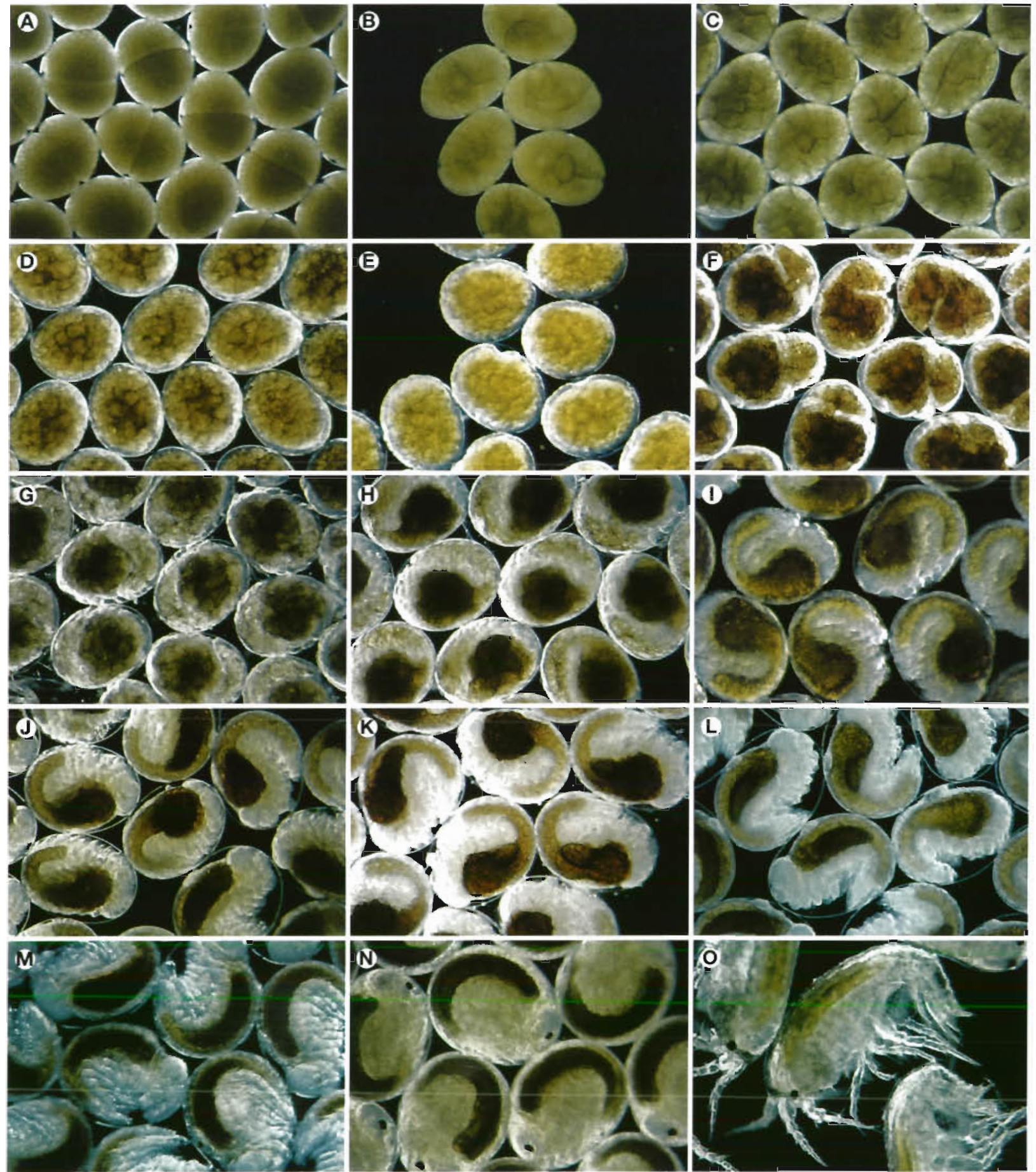

Fig. 3. Embryonic development of Monoporeia affinis. (A, B) Stage 1; (C) Stage 2; (D) Stage 3; (E, F) Stage 4; (G, H) Stage 5; (I-K) Stage 6 ; (L, M) Stage 7 ; (N) Stage 8 ; (O) Stage 9 . For details see Table 2 and text

3 to $4 \mathrm{wk}$ after hatching and it is probable that juveniles stay within the marsupium until the yolk is consumed. The whole embryogenesis takes about 3.5 mo for the majority of females at investigated stations ( 32 to $40 \mathrm{~m}$ depth) in the Baltic proper and the Baltic Sea
(55 to $140 \mathrm{~m}$ depth), which means that most females have released their juveniles at the end of March as a temporal adaptation to the phytoplankton spring bloom. Once the brood is released, the female does not survive for long. 

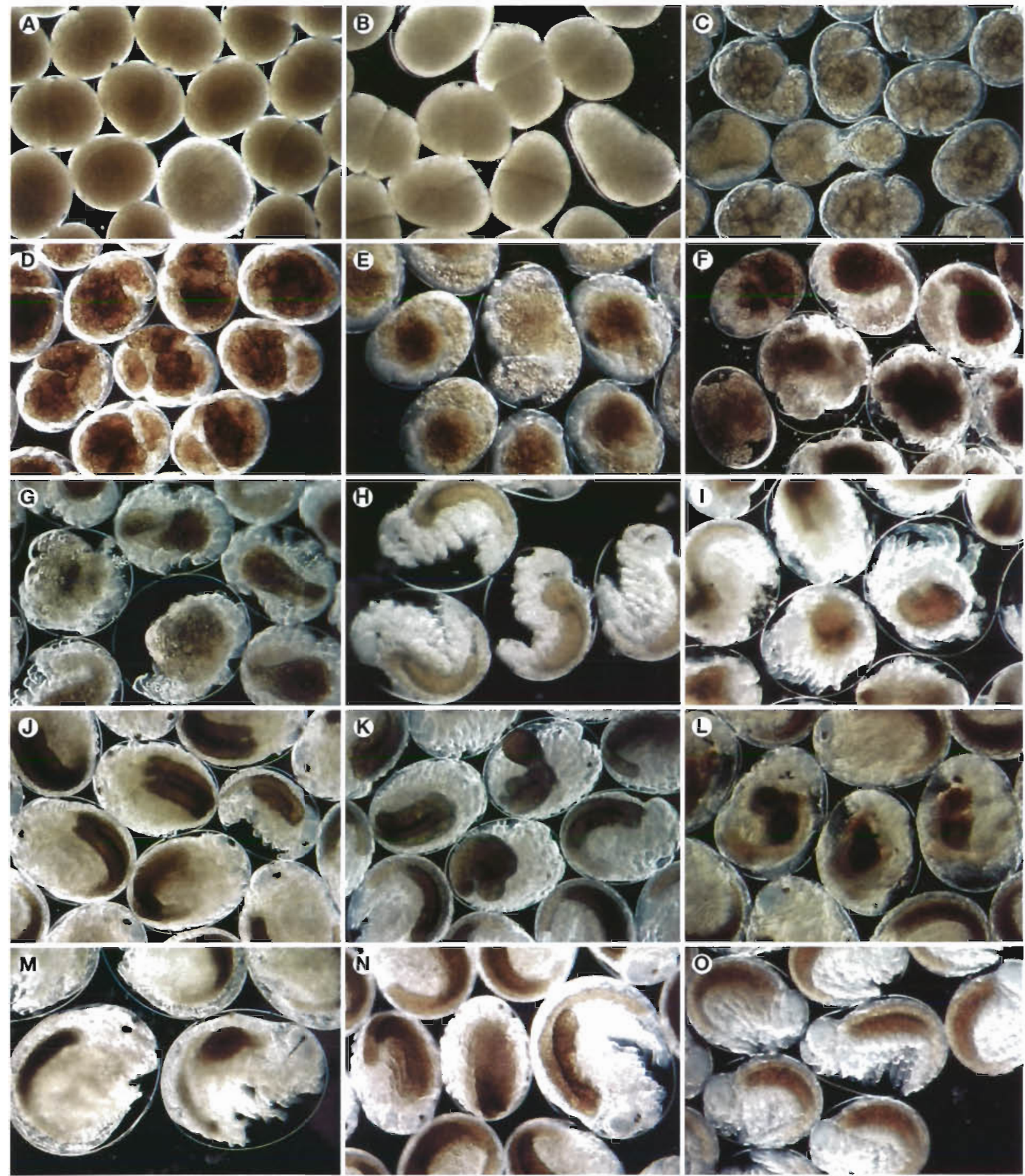

Fig. 4. Monoporeia affinis. (A-M) Malformed embryos of the amphipod at different developmental stages. ( $F, I, J, K, L)$ Nonspecific malformations; ( $A, B, C, D, E, G$ ) oedema and impaired membranes where lipids had leaked outside the embryo. (M) Malformed eyespot; ( $N, O)$ enlarged embryos with no other visible damage

Disturbed embryonic development

About $96 \%$ of embryos sampled at the reference sites showed a normal development, but there are some which did not develop normally. Results from 4 yr
(1994 to 1997) in the Baltic proper and the Bothnian Sea, where gravid females of Monoporeia affinis were sampled in the beginning of February, showed a frequency of 2 to $6 \%$ malformed embryos, 0 to $5 \%$ undifferentiated and 0 to $6 \%$ dead eggs. 

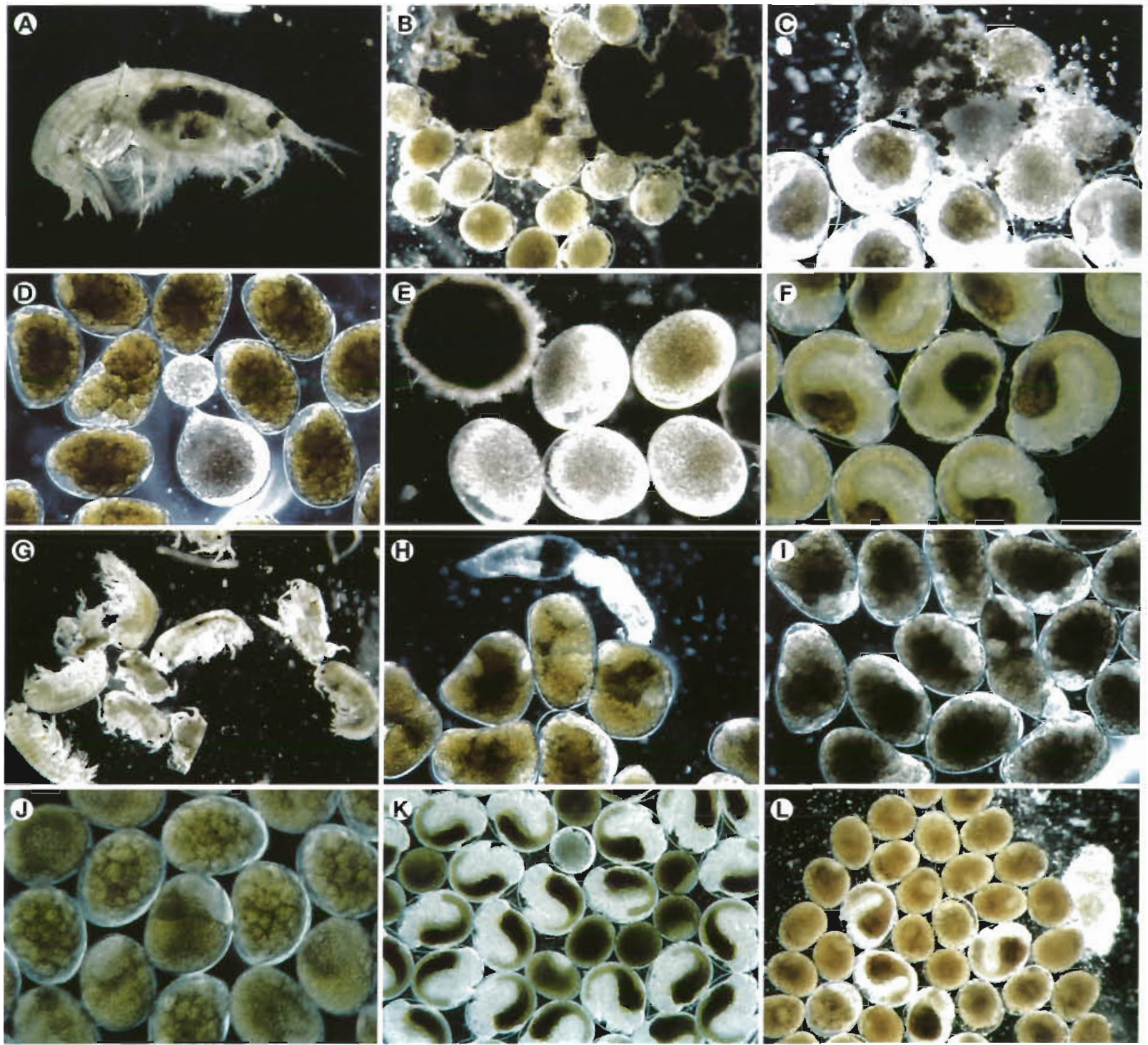

Fig. 5. Aberrant embryonic development of the amphipod Monoporeia affinis. (A) Female with dead brood. (B, C) Unidentified dead eggs of a brood. (D-G) Single dead eggs and juveniles. (H-J) Embryos with aberrant cleavages in the early embryogenesis. $(K, L)$ Undifferentiated embryos in which cells have degenerated

\section{Monitoring embryonic variables in recipients}

There was $98 \%$ agreement between trained observers analysing 50 broods of Monoporeia affinis for developmental stage and malformed, enlarged, undifferentiated and dead embryos, indicating no problem in distinguishing anomalies. Different types of anomalies are illustrated in Figs. $4 \& 5$.

\section{Malformed embryos}

The frequency of malformed embryos per female (Fig. 6) decreased with increasing distance from the industries $\left(\mathrm{p}=0.004, \mathrm{p}=0.02\right.$ and $\mathrm{p}=0.06, \mathrm{R}^{2}=0.75$, $R^{2}=0.63$ and $R^{2}=0.54$ for surveys $B, C$ and $A$ respectively). Also the frequencies of females carrying broods including malformed embryos were significantly higher close to the industries as compared to reference stations ( $p=0.001$ ). The frequencies of malformations ranged between 4.8 and $15.3 \%$ close to the industries and decreased to between 1.5 and $4.9 \%$ with a mean of $3.0 \%$ in reference areas. The highest frequencies of malformations were observed near industry $C$, the aluminum smeltery, where a frequency of $15.3 \%$ was observed at Stn C6, $0.7 \mathrm{~km}$ from the smeltery (Fig. 6). High frequencies of malformations were also observed in survey $\mathrm{B}$ close to 

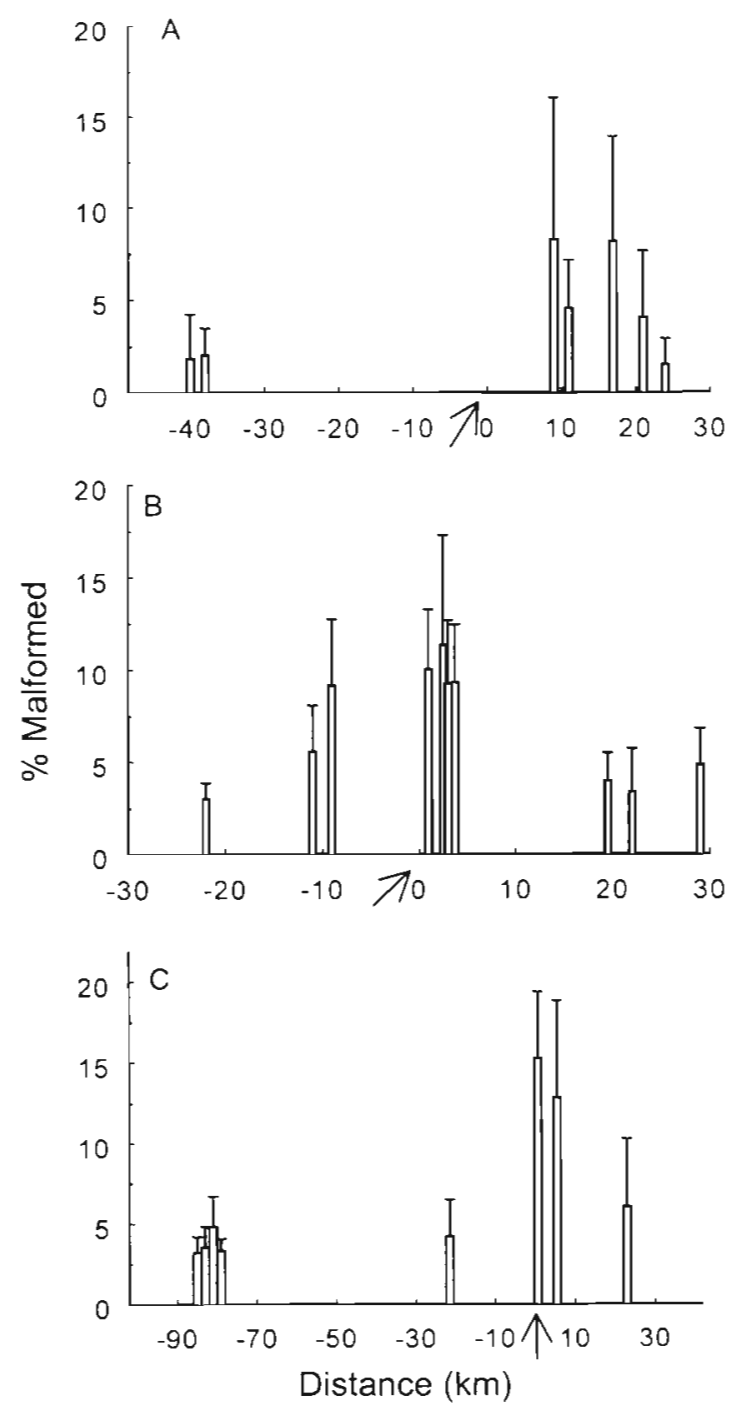

Fig. 6. Frequency of malformed embryos per female $(\bar{x} \pm \mathrm{Cl})$ of the amphipod Monoporeia affinis in surveys $\mathrm{A}, \mathrm{B}$ and $\mathrm{C}$. Stations located north of the industry are shown to the left, stations located south of the industry to the right. Industries are indicated with an arrow

the pulp mills: 9.3 to $11.4 \%$ at stations located 1 to $3.8 \mathrm{~km}$ from the pulp mills BI and BII and 4.6 to $8.3 \%$ at stations located 9 to $17 \mathrm{~km}$ from the pulp mill A (Fig. 6). Stns B2 and B3, situated $10 \mathrm{~km}$ north of the pulp mill, differed neither from recipient stations nor from more distant southwards reference stations. The lowest frequencies were abserved at the most distant northern references (Fig. 6) with the lowest expected influence from industrial effluents, possibly reflecting the main southward water current in the Baltic. Background levels of malformations were found at distances of 20 to $25 \mathrm{~km}$ from the different industries.

\section{Enlarged embryos with oedema}

Enlarged embryos with oedema were more frequent at the pulp mill stations in the Bothnian Sea $(p<0.05)$ and the Bothnian Bay $(p<0.0001)$ as compared to the reference stations (Fig. 7). The embryos were more or less enlarged, possibly because of changed permeability of membranes, which could have resulted in water transport through the egg membrane. Embryos were not tightly attached to the membrane and seemed to have partly lost contact with the egg membranes (Fig. 4N, O). Further, these embryos were fragile and burst easily. Since the enlarged embryos did not result in decreased juvenile hatching and survival we de-
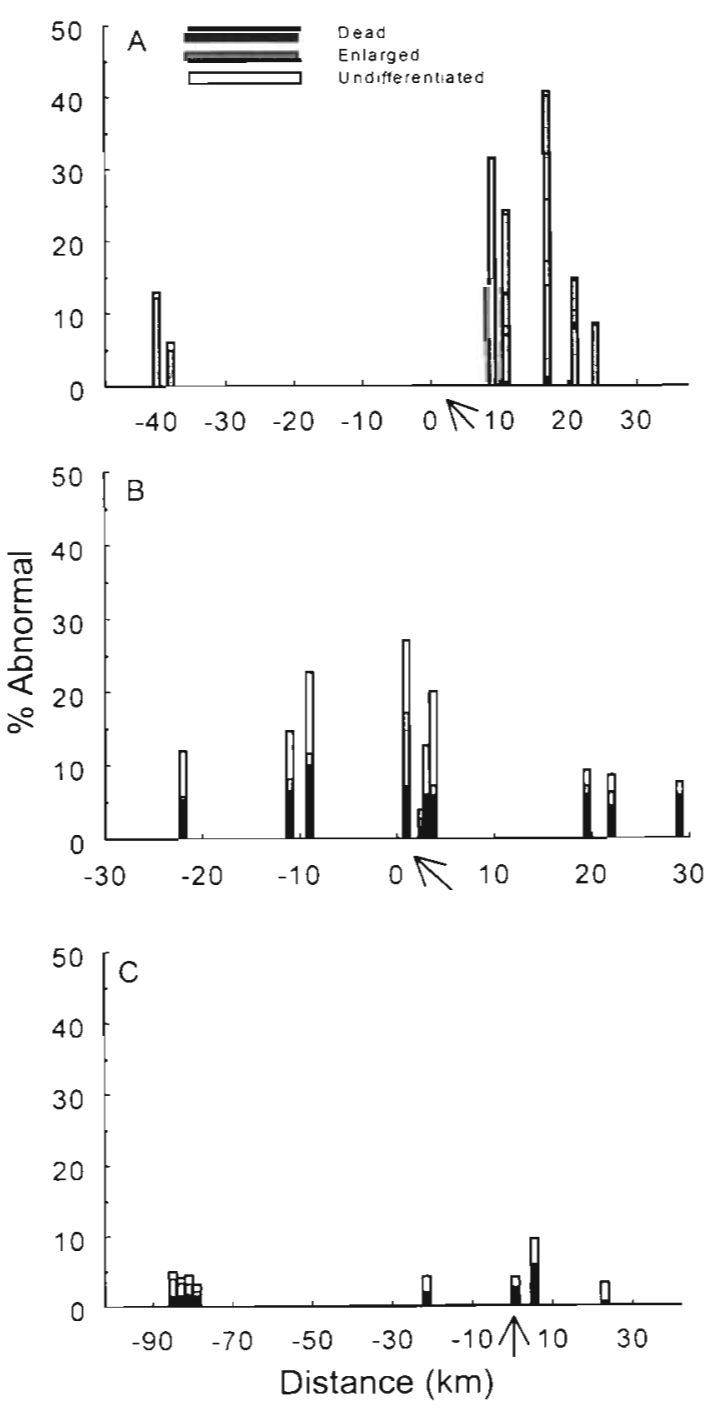

Fig. 7. Abnormal (enlarged, dead and undifferentiated) embryos per female of the amphipod Monoporeia affinis in surveys $A, B$ and $C$. Data are mean values. Stations located north of the industry are shown to the left, stations located south of the industry to the right. Industries are indicated with an arrow 
cided not to classify them as malformed. In the recipient of pulp mill $A_{1}$ including a bleaching stage, 23 to $40 \%$ enlarged embryos per female were observed, while lower frequencies ( 1.1 to $12 \%$ ) were observed in the receiving waters of pulp mill $B$, suggesting that the effluents were responsible for this aberration. However a low frequency $(1.1 \%)$ was observed at Stn B5, $0.7 \mathrm{~km}$ from pulp mill BI, indicating a weaker relationship to the exposure (Fig. 7). Background levels of 0.7 to $3.5 \%$ were observed outside the aluminum smeltery.

\section{Undifferentiated and dead embryos}

Undifferentiated and dead embryos per female did not differ between recipient and reference stations in surveys $A$ and $B$, while a high frequency of undifferentiated eggs at 1 recipient station and higher frequencies of dead eggs at reference sites of survey $C$ were recorded (Figs. 5B-G \& 7), suggesting that this damage arose independently of the industrial effluents. Normal background levels of undifferentiated and dead eggs were found in surveys $A$ and $C$. Survey $B$ in the Bothnian Bay showed normal frequencies of dead embryos $(0.3$ to $1.8 \%$ ) with the exception of a single station, B4, located $1 \mathrm{~km}$ away from pulp mill $\mathrm{BI}$, with a frequency of $10.1 \%$. Frequencies of undifferentiated embryos were overall comparatively high in survey $B$ as compared to surveys $A$ and $C$ (Figs. 5H-L \& 7 ) and background levels.

\section{Fecundity}

Fecundity (eggs per female) was affected differently in the 3 recipients (Fig. 8). Higher fecundity at stations near the mill resulted in a negative correlation between fecundity and distance from pulp mill $A(p<0.0001)$. Females sampled close to the mill (Stns A3, A4, A5) carried about 30 to 40 eggs, as compared to about 20 eggs per female at reference stations (Fig. 8). Females were generally larger at the near-mill stations and since fecundity is closely correlated to size (Cederwall 1977 , Leonardsson et al. 1988), it is suggested that substances in the BKME stimulated their growth. No correlation between fecundity and distance was observed in the recipient of pulp mills BI and BII, producing mainly unbleached pulp. Very high fecundity was observed at the most distant stations south and southeast of the pulp mills (Fig. 8). In contrast to survey A, females in survey $C$ were extremely small, and a negative effect on fecundity was observed. Stns C6 and C7 near the aluminum smeltery showed lower fecundity as compared to Stns C8 and C5 $(p<0.0001)$ and reference stations in the Bothnian Sea (Fig. 8). No correlation between fecundity and organic content of the sediments was found
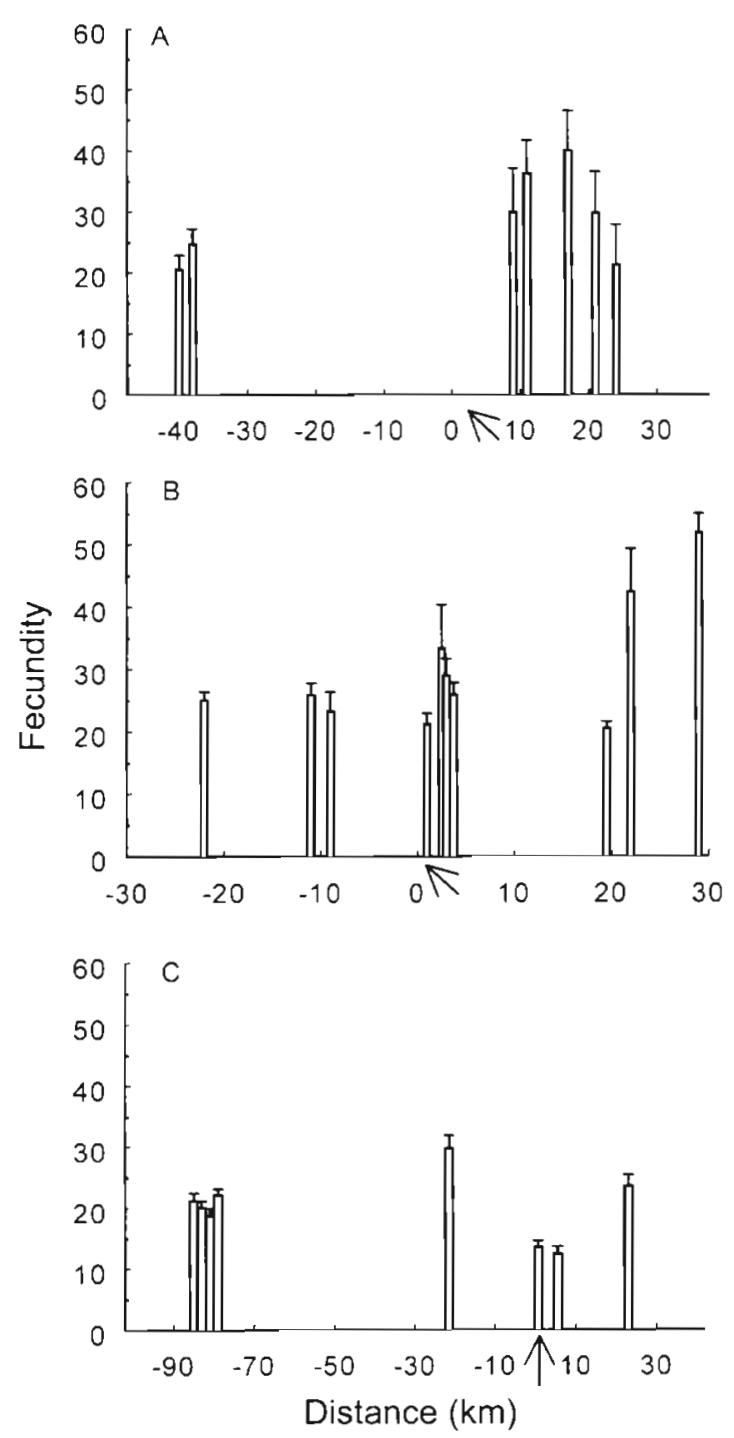

Fig. 8. Fecundity estimated as eggs per female $(\bar{x} \pm C I)$ of the amphipod Monoporeia affinis in surveys A, B and C. Stations located north of the industry are shown to the left, stations located south of the industry to the right

at investigated stations. Comparatively low fecundity was observed at some stations in both surveys $C$ and $B$ with extremely high organic content of the sediments (probably depending on rich occurrence of green macrophytes, B8), indicating that this rough measure alone cannot explain the fecundity.

Rate of embryo development was not influenced by the industrial effluents and the developmental stages of embryos did not differ between recipient stations and references. Further, the stage of embryo development did not differ between the areas despite the differences in latitudinal positions, indicating that mating and fertilization occurred at the same time in different parts of the Baltic. 


\section{DISCUSSION}

Results presented here and in an earlier study of an oil spill (Elmgren et al. 1983) have shown the usefulness of malformed embryos of Monoporeia affinis as a so-called 'biomarker' in pollution monitoring. The biomarker approach was initially developed to chart the responses of individual organisms to increasing pollutant exposure and stress (Depledge et al. 1992). The use of these 'biomarkers' to evaluate pollution hazards has increased markedly in the past few years Various definitions of biomarkers have been proposed but we have used the definition by Depledge (1994) 'a biological response to a chemical or chemicals that gives a measure of toxic effect'.

Different anomalies and deformities of both invertebrates and fish have been used in the assessment of contaminated areas and increased levels of deformities in the menta of chironomid larvae have been observed in polluted fresh waters (Wiederholm 1984, Warwick 1988, 1990, Vermeulen 1995, Dickman \& Rygiel 1996). However, with the exceptions of studies by Dickman \& Rygiel (1996) and Bleeker et al. (1997), the chironomid deformities have not been experimentally induced in laboratory experiments with xenobiotics. Bird et al. (1995) observed high frequencies of deformities in 4 of 5 reference lakes. The various levels in reference lakes elucidate how important it is that before emphasizing different biological effects observed in ecosystems as an index of environmental degradation, it is necessary to consider the natural background levels of the variables. However, today a great effort is put into experiments that will lead to improved understanding of the induction mechanisms of chironomid deformities and to a refinement of their use in biomonitoring.

\section{Embryonic development of Monoporeia affinis follows the pattern for other amphipods}

\section{Normal embryonic development}

The normal embryonic development of Monoporeia affinis - as far as can be judged from the literaturefollows the pattern known for other amphipods (Bregazzi 1973, McCahon \& Pascoe 1988b, Lalitha et al. 1991). The main reason for describing the embryonic development of $M$. affinis was to facilitate the use of the embryo variables in field studies of sediment toxicity. It is hoped that this strategy of analyzing the frequency of malformed embryos still present in the marsupium of females can also be used for other amphipods in the in situ assessment of marine pollution and that the stage description for $M$. affinis embryos and their photographic documentation will facilitate such studies.
Normal variation of embryonic aberrations

Between 2 and $6 \%$ malformed, 0 and $5 \%$ undifferentiated and 0 and $6 \%$ dead eggs and embryos were found in reference areas of the northern Baltic proper and the Bothnian Sea. Information in reported papers about an aberrant embryonic development of amphipods is very limited (Langenbeck 1898, Roux 1933, Segerstråle 1937, Weygoldt 1958, Rappaport 1960, Ward 1985, Steele \& Steele 1986, McCahon \& Pascoe 1988b, Scholtz 1990, Lalitha et al. 1991). Bregazzi (1973) reported unfertilized eggs occasionally occurring in the broods of the amphipod Tryphosella kergueleni and Sheader \& Chia (1970) observed $27 \%$ 'diseased' broods of the amphipod Marinogammarus obtusatus around a sewer pipe. A few papers have reported frequencies of embryonic malformations in control series and reference areas of usually the same magnitude as in the Baltic Sea (Dixon 1983, Dixon \& Pollard 1985, Beiras \& His 1994). Since even reference areas in the Baltic are slightly contaminated, it is impossible to separate possible effects of low-level pollution from 'normal' aberration due to e.g. spontaneous mutations, but considering data in the cited literature it is suggested that our frequencies reflect the normal variation of the embryo aberrations in Baltic coastal areas.

\section{Higher frequencies of malformed embryos in the recipient areas}

The highest frequencies of malformed embryos were observed near the aluminum smeltery (industry $\mathrm{C}$ ), where high concentrations of PAHs were measured in settling particulate matter, bottom sediments and the sediment-dwelling bivalve Macoma balthica (Näf et al. 1994). PAHs have been reported as toxic to crustaceans and effects on growth, development time and reproductive output have been observed (Neff 1985, Geiger \& Buikema 1992). Since pulp mills north of the recipient aera might also have contributed to the observed effects, it is impossible to distinguish the separate effects of PAHs. However, as compared to effects recorded in pulp mill recipient areas, the observed effects on embryogenesis are high. A fish survey performed half a year later in the area showed an increased level of DNA adducts in livers of perch. The adduct pattern showed the specific fingerprint of PAHs (Ericson et al. 1998).

Lack of amphipods at Stn A0 resulted in the more distant location of sampling sites in survey A as compared to survey $B$. Despite different processing techniques at the pulp mills, the impact was similar, particularly when considering the distances to the mills. Bleached kraft mill effluents (BKME) have caused the 
disappearance of benthic invertebrates and a higher incidence of embryo malformations and fish diseases (Sundelin 1988, 1989, Södergren et al. 1993, Sundelin \& Eriksson 1996). Kankaanpää et al. (1995) reported reduced swimming activity of Monoporeia affinis when exposed to BKME containing $8.3 \mathrm{mg} \mathrm{g}^{-1}$ organic chlorine expressed as adsorbable organic halogen (AOX)

\section{A weaker correlation between enlarged embryos and the industrial effluents}

Extremely high frequencies of enlarged embryos were observed outside industry $A$ in the Bothnian Sea with a bleaching process. High frequencies were also observed outside the pulp mills in the Bothnian Bay. The lowest frequencies were found outside the aluminum smeltery (survey C), showing nearly background levels, which is somewhat surprising considering the nearby pulp mills north of the recipient area. Further, 1 recipient station in survey $B$ showed very low frequencies of enlarged embryos, indicating a more vague connection to the industrial effluents for this damage than for malformations.

\section{Undifferentiated and dead embryos did not increase near the industries}

For undifferentiated and dead eggs there is no obvious correlation with the industrial effluents. With the exception of Stn B4, all recipient stations showed comparatively low frequencies of dead eggs per female. Results from the monitoring programme in the Baltic proper have shown a correlation between oxygen concentrations in bottom water and females with entirely or partly dead broods (Cederwall et al. 1998). Oxygen depletion was the main factor affecting the benthos near pulp mills 10 to $20 \mathrm{yr}$ ago, but substantial decreases in total wastewater and chemical oxygen demand (COD) discharges in effluents of Swedish pulp mills during the last 10 yr have resulted in improved oxygen conditions in sediments of pulp mill recipient area, and all stations were oxidised in the surface sediment layer.

\section{Effects on fecundity differ with the type of industrial effluents}

Different effects on fecundity were observed outside the industries. The significantly higher fecundity observed near pulp mill A was not recorded in survey $B$. Larger females were found near mill $A$ and the positive effect on fecundity is suggested simply to depend on larger female body size. In addition to its toxic effects, BKME is growth-stimulating to Monoporeia affinis. In the laboratory, $0.5 \%$ BKME added to sediments sampled close to the mill increased growth and survival of amphipods, while the frequency of malformed embryos increased (Sundelin 1989). The positive effects on fecundity by effluents of pulp mill A were not recorded outside mill B, producing unbleached pulp. However, there are no reported surveys showing growth-stimulating properties of effluents from nonbleaching processes.

In contrast lower fecundity of Monoporeia affinis was observed at Stns C6 and C7 close to the sites where Näf et al. (1994) reported concentrations of $210 \mu \mathrm{g} \mathrm{g}^{-1}$ PAHs (dry wt) in the sediment. At these sites, females were extremely small. Since amphipod fecundity (Samter \& Weltner 1904, Cederwall 1977, Kolding \& Fenchel 1981, Leonardsson et al. 1988) is closely correlated to size, it is suggested that growth has been affected. As the organic content of sediment was comparatively high, food shortage is unlikely. Ericson et al. (1998) reported decreased growth of perch in the area. PAHs have been reported to affect growth, feeding rate and development (Neff 1985, Geiger \& Buikema 1992, Carman et al. 1995, Lotufo 1997).

\section{Usage of reproduction variables as biomarkers to assess effects of chemical pollutants}

Increased sensitivity to pollutants during the reproductive period of many crustaceans has been reported (Buikema \& Benfield 1979) and sexually mature females and ovigerous females were particularly sensitive (McCahon \& Pascoe 1988a, b). Embryogenesis is often the period in the life cycle of organisms most sensitive to adverse conditions (Olsson et al. 1990, EPA 1991). Embryos and larvae of invertebrates have often been used in toxicity tests on account of their sensitivity (Calabrese \& Nelson 1974, Calabrese et al. 1977, Marshall 1978, Pagano et al. 1982, Ringwood \& Brouwer 1995, Wong et al. 1995, Timmermans et al. 1996). However, most papers only report effects on survival and growth of the early life stages. When deformations are recorded, they are usually not highlighted and the type and frequency of embryonic malformation are seldom used for monitoring effects of pollutants. An exception is the study by Lee et al. (1996), who found deformed eyespots and reduced hatching of embryos of the blue crab during exposure to cadmium, copper, tributyltin and endosulfan.

Despite the substantial literature about toxic effects on reproduction of crustaceans and other benthic invertebrates in the laboratory there are very few stud- 
ies on reproduction disturbances caused by chemicals in the field (Davey et al. 1983). One reason is the difficulty of establishing causal relationships when manipulations cannot be done. Another reason is the choice of variables, which often do not respond exclusively to anthropogenic pollutants. Most studies reviewed by Davey et al. (1983) use counts of number of individuals or number of eggs per brood in a polluted compared to a control area and particular attention has been paid to whether a given organism produces a few large or many small eggs (Clarke et al. 1985). Such data do not in themselves say anything about reproductive processes. So far little interest has been focused on fertilization success and embryonic development when dicussing mechanisms determining population dynamics. Birge et al. (1980) suggest that a survival decrease of about $10 \%$ during the embryogenesis or the larval stage would significantly affect population dynamics in natural communities. Sheehan (1984) suggests, on the basis of the results of Birge et al. (1977, 1978, 1980) and Cooke (1981), that monitoring the number of abnormal larvae or embryos in contaminated aquatic ecosystems may provide an estimate of the severity of environmental stress. Dixon \& Pollard (1985) reported that the frequency of abnormal embryos in the marsupium of the periwinkle Littorina saxatilis reflects the degree of anthropogenic stress to which populations have been exposed. The behaviour of amphipods and other species that carry their batch of eggs in the marsupium during embryogenesis greatly facilitates assessment of the effects on reproduction as compared to most fish species (pelagic fertilization) and mussels (pelagic embryogenesis). Our results indicate that the frequency of malformed embryos still present in the marsupium of females is a highly toxicant-sensitive variable and thus suitable for monitoring contaminated sediments.

\section{CONCLUSIONS}

The observed frequencies of aberrant embryos in the reference areas of the Baltic are suggested to reflect the normal, background level.

The frequencies of malformed embryos were higher near industrial pollution sources as compared to reference stations, indicating that industrial effluents were responsible for the increase. The frequency of malformed embryos was also elevated when other reproduction variables such as fecundity, reproduction success, developmental stage of embryos as well as population variables such as abundance and biomass of both macrofauna and meiofauna were unaffected (Sundelin 1992), suggesting frequency of the malformation is a variable particularly sensitive to pollutants.
A significant increase of abnormal embryos will result in impaired reproduction success, which may be impossible to detect by analysing other, more pollutantinsensitive variables. Thus, by analysing the number of malformed embryos of Monoporeia affinis we can provide an early warning that populations are at risk

Enlarged embryos with oedema occurred more frequently near pulp and paper mills, particularly near the pulp mill with a bleaching stage, but the variable showed a weaker correlation with the industrial effluents than malformed embryos. Further, in contrast to malformed embryos, hatching success of these embryos was not decreased in comparison with controls. Thus, this effect seems to be of minor importance for embryo survival and gives limited information about effects on populations.

Other embryo variables, such as undifferentiated and dead eggs, did not correlate to the industrial effluents, suggesting that causes other than xenobiotics were responsible for these reproductive losses.

The embryo development of Monoporeia affinis follows a pattern similar to that of related amphipods, and the description of the stages of embryonic development of $M$. affinis given here may facilitate similar studies on other amphipod species. The strategy of analyzing the frequency of malformed embryos still present in the marsupium of females in the in situ assessment of marine pollution might be suitable for all species carrying their broods

Acknowledgements. These surveys were supported by grants from Gränges Metall, AssiDomän, SCA and Swedish EPA to B.S. We are especially gratefuil to $\mathrm{S}$. $\AA$. Heinemo and $\mathrm{U}$. Strömberg at the County Administrations of Västernorrland and Norrbotten for initiating surveys B and $C$ and for help with collecting animals. Further, we thank E. Håkansson who helped collect animals and set up experiments, B. E. Bengtsson, R. Elmgren, U, Larsson for critical reading of the manuscript, J. O. Strömberg (for special valuable information on the embryogenesis) and $M$. Cronwall for linguistic revision.

\section{LITERATURE CITED}

Andersin AB, Lassig J, Sandler $H$ (1984) On the biology and production of Pontoporeia affinis Lindstrom in the gulf of Bothnia. Limnologica 15(2):395-401

Beiras R, His E (1994) Effects of dissolved mercury on embryogenesis, survival, growth and metamorphosis of Crassostrea gigas oyster larvae. Mar Ecol Prog Ser 113: 95-103

Bird GA, Rosentreter MJ, Schwartz WJ (1995) Deformities in the menta of chironomid larvae from the Experimental Lakes Area, Ontario. Can J Fish Aquat Sci 52:2290-2295

Birge WJ, Black JA, Kuehne RA (1980) Effects of organic compounds on amphibian reproduction. Research Report 121, Water Resources Research Institute, University of Kentucky, Lexington

Birge WJ, Black JA, Westerman (1978) Effects of polychlori- 
nated biphenyl compounds and proposed PCB-replacement products on embryo larval stages of fish and amphibians. Research Report 118, Water Resources Research Institute, University of Kentucky, Lexington

Birge WJ, Black JA, Westerman AG, Francis PC, Hudson JE (1977) Embryopathic effects of waterborne and sediment accumulated cadmium, mercury and zinc on reproduction and survival of fish and amphibian populations in Kentucky. Research Report 100, Water Resources Research Institute, University of Kentucky, Lexington

Bleeker EAJ, Wind E, van der Geest HG, Klamer HJC, Kraak MHS, Vermeulen AC, Groendijk D (1997) Is there a relationship between direct toxic, genotoxic and teratogenic effects of NPAHs to the midge Chironomus riparius? Abstract, 7th annual meeting of SETAC-Europe, Amsterdam, April 6-10, 1997. SETAC Press, Brussels

Blomqvist S, Abrahamsson B (1985) An improved kajak-type gravity core sampler for soft bottom sediments. Schweiz Z Hydrol 47(1):81-84

Blomqvist S, Lundgren L (1996) A benthic sled for sampling soft bottoms. Helgoländer Meeresunters 50:453-456

Bregazzi PK (1973) Embryological development in Tryphosella kergueleni (Miers) and Cheirimedon femoratus (Pfeffer) (Crustacea: Amphipoda). Br Antarct Surv Bull 32 $63-74$

Buikema AL, Benfield EF (1979) Use of macroinvertebrate life history information in toxicity tests. J Fish Res Bd Can 36: $321-328$

Calabrese A, McInnes DA, Nelson DA, Miller JE (1977) Survival and growth of bivalve larvae under heavy-metal stress. Mar Biol 41:179-184

Calabrese A, Nelson DA (1974) Inhibition of embryonic development of the hard clam Mercenaria mercenaria, by heavy metals. Bull Environ Contam Toxicol 11(1):92-97

Carman KR, Fleeger JW, Means JC, Pomarico SM, McMillin DJ (1995) Experimental investigation of the effects of polynuclear aromatic hydrocarbons on an estuarine sediment food web. Mar Environ Res 40(3):289-318

Cederwall $\mathrm{H}$ (1977) Annual macrofauna production of a soft bottom in the northern Baltic proper. In: Keegan BF, O'Ceidigh P, Boadan PJS (eds) Biology of benthic organisms. 11th Eur Mar Biol Symp. Pergamon Press, Oxford, p $155-164$

Cederwall $H$, Sundelin B, Eriksson AK, Håkansson E, Andersson LC (1998) Bottom water and soft bottom fauna. In Wulff F (ed) Östersjö 97. SMF, Stockholm (in press)

Clarke A, Skadsheim A, Holmes LJ (1985) Lipid biochemistry and reproductive biology in two species of Gammaridae (Crustacea: Amphipoda). Mar Biol 88:247-263

Conlan K (1994) Amphipoda crustaceans and environmental disturbance: a review. J Nat Hist 28:519-554

Cooke AS (1981) Tadpoles as indicators of harmful levels of pollution in the field. Environ Poll (Ser A) 25:123-133

Coyle KO, Highsmith RC (1994) Benthic amphipod community in the northern Bering Sea: analysis of potential structuring mechanisms. Mar Ecol Prog Ser 107:233-244

Davey KG, Saleuddin ASM, Steel CGH, Webb RA (1983) Methods for assessing the effects of chemicals on reproductive function, Invertebrates: some principals and recommendations. In: Vouk VB, Sheehan PJ (eds) Methods for assessing the effects of chemicals on reproductive functions. SCOPE 20, John Wiley \& Sons, Ltd, Chichester, p $483-497$

Davis GE (1993) Design elements of monitoring programs: the necessary ingredients for success. Environ Monit Assess 26:00-105

Depledge MH (1994) The rational basis for the use of bio- markers as ecotoxicological tools. In: Fossi MC, Leonzio $C$ (eds) Nondestructive biomarkers in vertebrates. Lewis Publishers, Boca Raton, p 271-295

Depledge $\mathrm{MH}$, Amaral-Medes JJ, Daniel B, Halbrook $\mathrm{R}_{t}$ Kloepper-Sams P, Moore M, Peakall DB (1992) The conceptual basis of the biomarker approach. In: Peakall DB, Shugart LR (eds) Biomarkers: research and application in the assessment of environmental health. NATO ASI Series H, Vol 68, Cell biology. Springer-Verlag, Berlin, p $15-29$

Dickman M, Rygiel G (1996) Chironomid larval deformity frequencies, mortality, and diversity in heavy-metal contaminated sediments of a Canadian riverine wetland. Environ Int 22(6):693-703

Dixon DR (1983) Methods for assessing the effects of chemicals on reproductive function in marine molluscs. In: Vouk VB, Sheehan PJ (eds) Methods for assessing the effects of chemicals on reproductive functions. SCOPE 20, John Wiley \& Sons, Ltd, Chichester, p 439-457

Dixon DR, Pollard D (1985) Embryo abnormalities in the periwinkle, Littorina saxatilis, as indicators of stress in polluted marine environments. Mar Pollut Bull 16(1):29-33

Elmgren R, Ankar S, Ejdung G (1986) Adult interference with postlarvae in soft sediments: the Pontoporeia-Macoma example. Ecology 64(4):827-836

Elmgren $R$, Hansson $S$, Larsson U, Sundelin B, Boehm $P$ (1983) The 'Tsesis' oil. spill: acute and long-term impact on the benthos. Mar Biol 73:51-65

EPA (Environmental Protection Agency) (1991) Technical support document for water quality-based toxins control. EPA/505/2-90-001, PB 91-127415. EPA, Washington, DC

Ericson G, Lindesjöö E, Balk L (1998) DNA adducts and histopathological lesions in perch (Perca fluviatilis) and northern pike (Esox lucius) along a polycyclic aromatic hydrocarbon gradient on the Swedish coastline of the Baltic Sea. Can J Fish Aquat Sci 55:815--824

Eriksson AK, Sundelin B, Broman D, Näf C (1996) Effects on Monoporeia affinis of HPLC-fractionated extracts of bottom sediments from a pulp mill recipient. In: Servos MR, Munkittrick KR, Carey JH, Van Der Kraak GJ (eds) Environmental fate and effects of pulp and paper mill effluents. St Lucie Press, Delray Beach, FL, p 69-78

Förstner U (1987) Sediment-associated contaminants-an overview of scientific bases for developing remedial options. Hydrobiologia 149:221-246

Geiger JG, Buikema AL (1992) Hydrocarbons depress growth and reproduction of Daphnia pulex (Cladocera). Can J Fish Aquat Sci 39:830-836

Giere OG (1993) Meio-benthology, the microscopic fauna in aquatic sediments. Springer-Verlag, Berlin

Hil] $C$ (1991) Mechanisms influencing the growth, reproduction, and mortality of two co-occurring amphipod species in the Baltic sea. Dissertation, University of Stockholm

Holm S (1979) A simple sequentially rejective multiple test procedure. Scand J Statist 6:65-70

Holton VC, Putnam HD, Evans DL (1993) Evaluating aquatic macroinvertebrate communities in the vicinity of a kraft mill discharge. Tappi J 76(1):99-108

Kankaanpää $H_{1}$ Laurén $M$, Mattson M, Lindström M (1995) Effects of bleached kraft mill effluents on the swimming activity of Monoporeia affinis (Crustacea, Amphipoda) Lindström. Chemosphere 31(11/12):4455-4473

Kolding S. Fenchel TM (1981) Patterns of reproduction in different populations of five species of the amphipod genus Gammarus. Oikos 37:167-172

Lalitha M. Shyamasundari K, Hanumantha Rao K (1991) Embryological development in Orchestia platensis kroyer 
(Crustacea: Amphipoda). Uttar Pradesh J Zool 11(2): $107-112$

Landrum PF, Robbins JA (1990) Bioavailability of sedimentassociated contaminants to benthic invertebrates. In: Baudo R, Giesy JP, Muntau H (eds) Sediments, chemistry and toxicity of in-place pollutants, Chapter 8 . Lewis Publishers, Ann Arbor, MI, p 237-263

Langenbeck $C$ (1898) Formation of the germ layers in the amphipod Microdeutopus gryllotalpa costa. J Morphol 14: 301-336

Lee RF, O'Malley K, Oshima Y (1996) Effects of toxicants on developing oocytes and embryos of the blue crab Callinectes sapidus. Mar Environ Res 42(1-4):125-128

Leonardsson K (1994) Multiple density dependence in two sub-populations of amphipod Monoporeia affinis: a potential for alternative equilibria. Oecologia 97:26-34

Leonardsson K. Sörlin T, Samberg H (1988) Does Pontoporeia affinis (Amphipoda) optimize age at reproduction in the Gulf of Bothnia? Oikos 52:328-336

Lindström M (1992) The migration behaviour of the amphipod Pontoporeia affinis (Lindström). Walter and Andrée de Nottbeck Foundation Scientific Reports No. 7. Dissertation, University of Helsinki

Lopez G, Elmgren R (1989) Feeding depths and organic absorption for the deposit-feeding benthic amphipods Pontoporeia affinis and Pontoporeia femorata. Limnol Oceanogr 34(6):982-991

Lotufo GR (1997) Toxicity of sediment-associated PAHs to an estuarine copepod: effects on survival, feeding, reproduction and behaviour. Mar Environ Res 44(2):149-166

Marshall J (1978) Population dynamics of Daphnia galeata mendotae as modified by chronic cadmium stress. J Fish Res Bd Can 35:461-469

McCahon CP, Pascoe D (1988a) Use of Gammarus pulex (L.) in safety evaluations tests: culture and selections of a sensitive life stage. Ecotoxicol Environ Saf 15:245-252

McCahon CP, Pascoe D (1988b) Increased sensitivity to cadmium of the freshwater amphipod Gammarus pulex (L.) during the reproductive period. Aquat Toxicol 13:183-194

Moore JW, Beaubien VA, Sutherland DJ (1979) Comparative effects of sediment and water contamination on benthic invertebrates in four lakes. Bull Environ Contam Toxicol 23:840-847

Näf C, Broman D, Pettersen H, Rolff C, Zebühr Y (1992) Flux estimates and pattern recognition of particulate polycyclic aromatic hydrocarbons, polychlorinated dibenzo-p-dioxins, and dibenzofurans in the waters outside various emission sources on the Swedish Baltic Coast. Environ Sci Tech $26(7): 1444-1457$

Näf C, Broman D, Axelman J (1994) Characterisation of PAH load outside an aluminum smelter on the Swedish Baltic coast. Sci Total Environ 156:109-118

Neff JM (1985) Polycyclic aromatic hydrocarbons. In: Rand GM, Petrocelli SR (eds) Fundamentals of aquatic toxicology. Hemisphere, New York, p 416-454

Ólafsson E, Elmgren R (1991) Effects of biological disturbance by benthic amphipods Monoporeia affinis on meiobenthic community structure: a laboratory approach. Mar Ecol Prog Ser 74:99-107

Olsson PE, Zafarulla M, Foster R, Harmor T, Gedamu L (1990) Developmental regulation of metallothionein mRNA, zinc and copper levels in rainbow trout, Salmo gairdneri. Eur J Biochem 193:223-235

Pagano G, Esposito A, Giordano GG (1982) Fertilization and larval development in sea urchins following exposure of gametes and embryos to cadmium. Arch Environ Contam Toxicol 11:47-55
Pearson TH (1975) The benthic ecology of Loch Linnhe and Loch Eil, and a sea-loch system on the west coast of Scotland. IV. Changes in the fauna attributable to organic enrichment. J Exp Mar Biol Ecol 20:1-41

Powers CF, Robertson A (1967) Design and evaluation of an all-purpose benthos sampler. In: Ayers JC, Chandler DC (eds) Studies on the environment and eutrophication of Lake Michigan. Univ of Michigan, Great Lakes Res Div Spec Rep 30:126-131

Rappaport R Jr (1960) The origin and formation of blastoderm cells of gammarid Crustacea. J Exp Zool 144:43-59

Ringwood AH, Brouwer M (1995) Patterns of metallothionein expression in oyster embryos. Mar Environ Res 39:101-105

Roux MLL (1933) Recherches sur la sexualité des Gammariens. Bull Biol (Suppl) 16:1-139

Samter M. Weltner W (1904) Biologische Eigentümlichkeiten der Mysis relicta, Pallasea quadrispinosa und Pontoporeia affinis erklärt aus ihrer eiszeitlichen Entstehung. Zool Anz $27(22): 676-694$

Sarvala J, Uitto A (1991) Production of benthic amphipods Pontoporeia affinis and $P$. femorata in a Baltic archipelago Ophelia 34(2):71-90

Scholtz G (1990) The formation, differentiation and segmentation of the post-naupliar germ band of the amphipod Gammarus pulex L. (Crustacea, Malacostraca, Peracarida). Proc R Soc Lond B 239:163-211

Segerstråle SG (1937) Studien über die Bodentierwelt in südfinnländischen Küstengewässern III. Zur Morphologie und Biologie des Amphipoden Pontoporeia affinis, nebst einer Revision der Pontoporeia-Systematik. Soc Scient Fenn Comment Biol 7(1):1-183

Segerstråle SC (1967) Observations of summer-breeding in populations of the glacial relict. Pontoporeia affinis Lindstrom (Crustacea Amphipoda), living at the greater depths in the Baltic Sea, with notes on the reproduction of $P$. femorata Kröyer. J Exp Mar Biol Ecol 1:55-64

Segerstråle SG (1970) Light control of the reproductive cycle of Pontoporeia affinis Lindström (Crustacea Amphipoda). $J$ Exp Mar Biol Ecol 5:272-275

Segerstråle SG (1971) Light and gonad development in Pontoporeia affinis. In: Crisp D (ed) 4th Eur Mar Biol Symp 1969. Cambridge University Press, London, p 573-581

Sheader M, Chia FS (1970) Development, fecundity and brooding behaviour of the amphipod, Marinogammarus obtusatus. J Mar Biol Assoc UK 50:1079-1099

Sheehan PJ (1984) Effects on individuals and populations. In Sheehan PJ, Miller DR, Butler GC, Bourdeau P (eds) Effects of pollutants at the ecosystem level. SCOPE 22, John Wiley \& Sons Ltd, Chichester, p 23-50

Södergren A, Adofsson-Erici M, Bengtsson BE, Jonsson P, Lagergren S, Rahm L, Wulff F (1993) Environmental impact of bleached pulp mill effluents. In: Södergren $A$ (ed) Bleached pulp mill effluents - composition, fate and effects in the Baltic Sea. Report 4047, Swedish Environmental Protection Agency, Arlöw, p 26-48

Steele VJ, Steele DH (1986) The influence of photoperiod on timing of reproductive cycles in Gammarus species (Crustacea, Amphipoda). Am Zool 26:459-467

Sundelin B (1983) Effects of cadmium on Pontoporeia affinis (Crustacea: Amphipoda) in laboratory soft-bottom microcosms. Mar Biol 74:203-212

Sundelin B (1984) Single and combined effects of lead and cadmium on Pontoporeia affinis (Crustacea: Amphipoda) in laboratory soft-bottom microcosms. In: Persoone G, Jaspers E, Claus C (eds) Ecotoxicological testing for the marine environment, Vol 2. State Univ. Ghent and Inst Mar Scient Res, Bredene, p 237-259 
Sundelin B (1988) Effects of sulphate pulp mill effluents on soft-bottom organisms - a microcosm study. Wat Sci Tech 20(2): 175-177

Sundelin B (1989) Ecological effect assessment of pollutants using Baltic benthic organisms. Dissertation, Stockholm University

Sundelin B (1992) Effect monitoring in pulp mill areas using benthic macro- and meiofauna. In: Environmental fate and effects of bleached pulp mill effluents. Report 4031 , Swedish Environmental Protection Agency, Stockholm, p $371-380$

Sundelin B, Elmgren R (1991) The meiofauna of an experimental soft bottom ecosystem-the effects of a deposit feeding amphipod, Pontoporeia affinis and of cadmium exposure. Mar Ecol Prog Ser 70:245-255

Sundelin B, Eriksson AK (1996) Effect monitoring in pulp mill areas-response of the meiofauna community to altered process technique. In: Servos MR, Munkittrick KR, Carey JH, Van Der Kraak GJ (eds) (eds) Environmental fate and effects of pulp and paper mill effluents. St Lucie Press, Delray Beach, FL, p 69-78

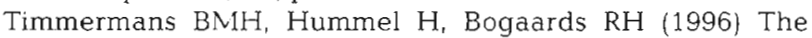
effect of polluted sediment on the gonadal development and embryogenesis of bivalves. Sci Tot Environ 187: $231-236$

Editorial responsibility: Otto Kinne (Editor), Oldendorf/Luhe, Germany
Vermeulen AC (1995) Elaborating chironomid deformities as bioindicators of toxic sediment stress: the potential application of mixture toxicity concepts. Ann Zool Fenn 32: $265-285$

Ward PI (1985) The breeding behaviour of Gammarus duebeni. Hydrobiologia 121:45-50

Warwick WF (1988) Morphological deformities in Chironomidae (Diptera) larvae as biological indicators of toxic stress. In: Evans MS (ed) Contaminants and ecosystem health; a Great Lakes focus. John Wiley and Sons, New York, p 281-320

Warwick WF (1990) The use of morphological deformities in chironomid larvae (Diptera: Chironomidae) for biological effects monitoring. Environ Can Inland Waters Dir Sci Ser $173(43): 1-34$

Weygoldt P (1958) Die Embryonalentwicklung des Amphipoden Gammarus pulex pulex (1.). Zool Jahresb (Anat) 77 : $51-110$

Wiederholm $\mathrm{T}$ (1984) Incidence of deformed chironomid larvae (Diptera: Chironomidae) in Swedish lakes. Hydrobiologia 109:243-249

Wong CK, Cheung JKY, Chu KH (1995) Effects of copper on survival, development and growth of Metapenaeus ensis larvae and postlarvae (Decapoda: Penaeidae). Mar Pollut Bull 31(4-12):416-419

Submitted: July 9, 1997; Accepted: June 8, 1998 Proofs received from author(s): August 26, 1998 